\title{
A kémiatudományok kezdetei Erdélyben
}

\section{Veress Erzsébet}

Beginnings of Chemistry Sciences in Transylvania. - Chemistry is perhaps the youngest of the natural sciences. "Protochemistry" appeared as the "byproduct" of alchemy: the first technologically really important chemicals (the mineral acids) were discovered during alchemists' experiments done in the hope of achieving of elements' transmutation. Chemistry as a science began some 400 years ago with the iatrochemistry of Theophrastus Bombastus von Hohenheim (Paracelsus, 1493-1541) and the printing of Georg Bauer's book (Agricola, 1494-1555), "De Re Metallica" (1556). The paper presents a short historical overview on the appearance and further development of chemical sciences in Transylvania, from the beginning up to 1959 (year of creation of the „Babeș-Bolyai” University at Kolozsvár/Cluj by the forced unification of the two Transylvanian Universities, the "Bolyai" and the "Victor Babeş"), as well as the influence of the scientific work done in Transylvania on the development of chemical sciences on the territory of the historical Hungary.

A kémia a természettudomány viszonylag fiatal, mindössze 3-400 éves ága, bár tudatos emberi tevékenységként sokkal régebbi. Tudománnyá válását az aranycsinálás titkát közel kétezer éven át kutató alkimisták kísérletezései indították el.

Az alkimisták a Kárpát-medencét mindig is számon tartották: Erdélyt bejárta Paracelsus, John Dee és Edward Kelley, és Hahnemann is Erdélyben eszmélt rá a homeopátia gondolatára. Az alkímia fénykorában Erdélyben az iránta való érdeklődés feltehetően ugyanolyan mértékü lehetett, mint bárhol Európában. Kevéssé ismert például, hogy Bercsényi Miklós kuruc generális (Temetvény, 1664 - Rodostó, 1726) folytatott alkimista tevékenységet is, még a harcokba is elvitte magával ládikáját, amelyben a fő kísérleti eszközeit tárolta. ${ }^{1}$

' Baji Lázár Imre: Ikonográf. Történelmi arcképcsarnok rejtett kontúrokkal. Ökotáj. 31-32. (2003), 23-42. 
Erdélyi alkimisták ennek dacára nem túl nagy számban ismeretesek, mindössze négyükről érdemes bővebben szólni.

Az első ismert, egyben a legnevesebb magyar alkimista, a nagyszebeni születésü Melchior Miklós a XV. század második felében született, II. Ulászló, majd II. Lajos udvarában élt, 1531-ben kísérletek során elkövetett csalásaiért Prágában lefejezték. Michael Maiernek az 1617-ben Frankfurtban megjelent Symbola Aureae Mensae Duodecim Nationum címủ könyve az említett tizenkét nemzet leghíresebb alkimistái között ismerteti, a címlapján levő képek egyike Ungarus elnevezés alatt Melchior Cibinensis arcképe. Az aranycsinálás módját szentmise formájában örökítette meg, kéziratos munkájának címe Processus universalis tincturae sub forma missae. Nehezen érthető, jelképekkel telített müve kora természettudományi ismereteire támaszkodott. A szöveg alapján kísérleteit ma nem egyszerü összeállítani, mivel azonban utóbb Libavius rottenburgi orvos (később hallei tanár) egyik munkájában idézi (Synt. Arc. Chymicorium, 1613), ennek és a Bécsben örzött kéziratnak segítségével ez nem lehetetlen. ${ }^{2}$

Kolozsvári Cementes János a nagybányai, majd a nagyszebeni bányánál dolgozott finomitóként, végül otthagyta Nagyszebent, és János Zsigmond fejedelem szolgálatába állt. Báthory István uralkodása idején már kamaraispán. A nagyszebeni pestisjárványban vesztette életét. Részben magyarul, részben latinul írott naplója a legrégebbi magyar alkímiai kézirat. A Nemzeti Múzeum kézirattárában őrzött napló az 1530-1586. éveket öleli fel. Megőrizte a régi magyar bányászati, kohászati és kémiai műszaki nyelvet, benne többek között egy Aquinói Szent Tamás által feljegyzett aranycsináló receptnek (az 1570-es évekből származó) magyar fordítását is olvashatjuk. ${ }^{3}$

A Nagybányán született Bánfihunyadi (Bánfy-Hunyady,Bánfi Hunyadi) János, más néven Hans Hungar (1576?-1646) a kor nemzetközileg legismertebb magyar tudósa volt. Vándorévei során Angliába kerülve a londoni Gresham College-ben tanitott (segédként) mennyiségtant és alkímiát - jatrokémiát, nem az aranycsinálás müvészetét. Korának neves vegyésze-

\footnotetext{
${ }^{2}$ Szathmáry László: Magyar alkémisták. Királyi Magyar Természettudományi Társulat, Budapest, 1928. Muzsnay Csaba: Apáczai Csere János, az erdélyi magyar tannyelvü egyetemi oktatás létrehozásának és a magyar szaknyelv kialakitásának elöharcosa. Müszaki Szemle, 34. (2006), 26-39. http://nyuz.elte.hu/archiv26/2601/tudleg.

${ }^{3}$ Szathmáry László: Aranycsináló recept magyar fordítása 1570-böl. A Magyar Gyógyszerésztudományi Társaság Értesitője, VI. (1930).
} 


\section{EME}

ként kapcsolatban állt az idő legismertebb alkimistáival. Nem sikerült hazatérnie: a visszaúton Amszterdamban meghalt. ${ }^{4}$

$\mathrm{Az}$ alkímia magyarországi fénykorának alkimistája, Bárótzi Sándor Ispánlakán született 1735. április 11-én. A nagyenyedi kollégium elvégzése után az erdélyi kancelláriában, majd 1760-tól Mária Terézia bécsi nemesi testörségében szolgált. Az alkímiával Bécsben, egy Székely László nevü alezredes révén került kapcsolatba, aki sikkasztásai fedezésére igyekezett aranyat készíteni. Harminc évig tanulmányozta az alkímiát, kísérletezett is vele. A Bárótzi nevéhez füződő egyetlen, magyar nyelven megjelent alkímiai munkát 1810-ben adták ki Bécsben, címe $A^{\prime}$ mostani Adeptus vagy is a' szabad kömivesek valóságos titka. A könyv egy francia mü (L'adepte moderne, ou le vrai secret des franc-maçon) alapján készült német változat (Der neue Goldmacher, oder das wahre Geheimnis der Freymaurer) fordítása, és La Croix francia adeptusz arany-csinálásáról és viszontagságairól szól. Bárótzi a könyv elé írt 70 oldalas, nagy tudással összeállított előszavában ismerteti az alkímia lényegét, elméletét, áttekinti fejlödését a régi görögöktől a kortárs szabadkőmúves alkimistákig, igyekszik megvédeni az alkímia tudományát a kételkedőkkel szemben.

Az aranycsináló magyar alkimistáknak ha nem sok szerepük is volt a kémia kialakulásában a történeti Magyarországon, az aranynak magának igen. A XVI. századtól kezdődően a természetbúvár tudósok figyelme az alkímia felöl át is terelödik az ásványtan felé. A XVII-XIX. században a vegyészet nem is különíthető el a bányászattól és a kohászattól. Mintegy száz évvel később pedig az ásványtan mellett újabb érdeklődési terület nyílik, az orvosi kémia: a kutató vegyész feladata lesz az orvosságok keresése, elóállítása is.

A középkori Magyarország Európa egyik legfontosabb aranytermelö országa. Erdélyben római kori leletek tanúskodnak a területen folytatott korai aranybányászatról. Már Szent István király veretett ezüstpénzt, 1325ben pedig Károly kibocsátja az első magyar aranypénzt. A pénz minőségének ellenőrzése fontos állami tevékenység volt. A beszolgáltatásra kerülö bányatermék értékét is csak úgy lehetett megállapítani, ha a nemesfém tartalmát meghatározták.

Szükséges volt tehát mind a feldolgozott aranyat, mind a kőzetet megvizsgálni, „megpróbáztatni”.

${ }^{4}$ Szathmáry László: i.m. 1928. Szathmáry László: A magyar iatrochemikusok. A Magyar Gyógyszerésztudományi Tärsaság Értesitöje, IX/5. (1933). 
Mint arra Károly Róbert király 1342-ben kiadott dekrétuma is utal, a vizsgálat szokásos módja a kupelláció (tűzpróba) volt, bár a karcpróbát is használták (a vizsgált tárggyal egy cserépen ejtett karcot ismert aranytartalmú tük karcával hasonlították össze).

Az első valódi vegyészek tehát az úgynevezett próbázók (probatores, Probierer), akik a pénz és a nemesfémek tisztaságát ellenőrizték. Személyükről nem sokat tudunk, legtöbbnek a nevét sem ismerjük. ${ }^{5}$ A kémia rövidesen felbukkan a kollégiumi, majd az egyetemi oktatásban, kezdetben a kor tudományos érdeklődésének megfelelően csupán a bányászat-kohászat, majd az orvostudomány keretében is. Oktatása Erdélyben a XVII. századtól adatolható.

Mint fennmaradt, a gyulafehérvári akadémián 1629 és 1638 között Johann Henrich Alsted a természettudományok keretében már kémiát is tanít. Kolozsváron, az 1656-ban alapított Református Kollégiumban pedig Apáczai Csere János (1625-1659) tanítja a természettudományokat, valószínü ásványtant is, hiszen 1655-ben megjelent Magyar Encyclopaediájában tág teret szentel a mineralógiai ismereteknek. A nagyenyedi kollégium tanára, Benkő Ferenc 1786-ban Kolozsváron Magyar mineralogia az az a' kövek 's értzek tudománya címmel megjelenteti az első magyar nyelvü mineralógiát, könyvében az ásványtant összemossa a kémiával. A marosvásárhelyi Református Kollégiumban 1804-től Bolyai Farkas tanít a kornak megfelelő színvonalon korszerü kémiát: sztöchiometriai számításokat, kísérletezést. Az erdélyi kollégiumok könyvtárában az Európa-szerte akkoriban kiadott fontosabb természettudományos munkák között ott vannak a vegytannal kapcsolatosak is. ${ }^{6}$ Végül a XVIII. század végén a bányászati-kohászati akadémia mellett megjelenik az első önálló főiskolai kémiai tanszék is.

Mivel, mint fentebb említettük, a XVII-XVIII. században a vegyész feladata az orvosságok keresése, elöállítása is, Európa-szerte, tehát Magyarországon is - és természetesen Erdélyben is - megkezdődik az ásványvizek, gyógyvizek vizsgálata. Az orvosok, kémiai ismereteiket hasznosítva, a vizek gyógyhatását az összetételből próbálták megállapítani. Erdély protofizikusa (főorvosa), Adam Chenot 1773-ban körlevélben fel is kéri az orvosi kart,

\footnotetext{
${ }^{5}$ Szabadváry Ferenc: A magyar kémia müvelödéstörténete. Mundus Magyar Egyetemi Kiadó, Bp., 1998.

${ }^{6}$ Hints Miklós: A vegytani érdeklődés kezdetei az erdélyi iskolákban. = Múzeumi Füzetek (új sorozat), 2. (1993), 38-49.
} 
hogy gyüjtsék össze az ásványvízadatokat, határozzák meg a gyógyvizek összetételét. A munkában az erdélyi felvilágosult orvosok első nemzedékéből Kibédi Mátyus István, a második nemzedékből Nyulas Ferenc, a harmadikból Gergelyffi András és Gyarmathy Sámuel vettek részt.

Mátyus István (Kibéd, 1725 - Marosvásárhely, 1802) Marosszék első orvosa, a magyar orvosi nyelv egyik megteremtője, a magyar táplálkozástudomány atyja. Diaetetica I-II és $O$ - és Új Diaetetica I-VI címü magyar nyelvủ köteteiben (1765, valamint 1792) adja közre vízvizsgáló módszereit, saját ásványvízelemzéseit (színre, átlátszóságra, szagra, ízre, súlyra, salakanyagaira, vegyi és fizikai természetre, tulajdonságokra nézve), és ismerteti azokat a forrásokat, amelyeket elsőnek elemzett. Beszámol a vizek gyógyászati javallatairól, illetve ellenjavallatairól, orvosi, gazdasági jelentőségükröl is. Johann Heinrich Crantz bécsi egyetemi tanár a Birodalom ásványvizeit átfogó müvében Mátyus István elemzéseit a legértékesebbek közé sorolja.

Mátyus István munkáját folytatva Nyulas Ferenc 1800-ban Az Erdély Országi Orvosi vizeknek bontásáról közönségesen címmel három kötetben megjelenteti az első magyar nyelvü, tulajdonképpeni analitikai kémiakönyvet (könyve tíz év munkáját foglalja össze), később pedig hathatósan támogatja Gergelyffi Andrást, Udvarhelyszék orvosát (1802-1808), aki majd a homoródi forrás elemzésével hívja fel magára a figyelmet. ${ }^{7}$

Nyulas Ferenc 1758-ben született Köszvényesremetén. ${ }^{8}$ Tanulmányait Kolozsvárott kezdte, majd Bécsbe ment orvostudományt tanulni, mivel erre otthon még nem volt lehetőség (a régi kolozsvári jezsuita kollégiumból kifejlödött Orvosisebészeti Intézetben csak 1837-ben szervezik meg a Kémiai és Botanikai Tanszéket, amelynek vezető professzora 1869-ig Joó István; távozása után a Kolozsvári Tudományegyetem orvosi karának felállításáig helyettes tanárokat alkalmaznak). Pesten szerzett orvosdoktori címet. Tanulmányai folytán ismerte a bányászati és kohászati kémiát és Lavoisier új antiflogisztikus vegytanát is. 1788-ban Szamosújváron vállalt orvosi állást. A Helytartótanács rendeletének megfelelően a Radna környéki vizeket elemezte, az akkor legkorszerübb analitikai módszerek felhasználásával. Szegényes eszközeivel igen pontos méréseket végzett. ${ }^{9} \mathrm{Az}$ általa elemzett

\footnotetext{
${ }^{7}$ Mátyus András: A szombatfalvi forrásvizek első magyar nyelvü leírása. = Udvarhelyi Híradó, XIV. évf., 197.

${ }^{8}$ Nyárádremete régi elnevezése (szerk. megj.).

' Kalydi György: Nyulas Ferenc. KÖKÉL, 31/1. (2004), www.kokel.mke.org.hu/2004_01/ szakmai/kk0401.
} 
ásványvizeket az 1950-es években ismét megvizsgálva közel azonos eredményeket kaptak.

Fontos, a tudományos világot csaknem száz évvel megelőző élelmiszerkémiai megállapítása, hogy a szén-dioxidot tartalmazó víz meggátolja a hús romlását. ${ }^{10}$

Munkássága azonban nem csak ebből a szempontból értékes. Nyulas Ferenc teremtette meg a magyar kémiai nyelvezetet. Néhány Nyulas által alkotott, azóta is használt szó: buborék, folyadék, kristály, lombik, pezsgés, szürö, tégely.

Az elismerés jeleként 1806-ban Erdély főorvosává választják. 1808-ban, 50 éves korában hunyt el.

Az 1850-es évektől a módszeres ásványvízkutatás összekapcsolódik a Keleti-Kárpátok-beli kőolaj- és földgázkutatással.

Köolajtartalmú ásványvizek létét a Székelyudvarhely melletti Szejkefürdő borvízforrásával kapcsolatban említik első alkalommal (Lucas Wagner, 1773). ${ }^{11} \mathrm{Az}$ érdemi, rendszeres munka mintegy száz évre rá kezdődik Sósmezőn, majd kutatnak Zabolán, Gelence mellett a Putna völgyében, a Gyimesekben, és Máramarosban az Iza-völgyben: Dragomérfalva, Felsőszelistye és Batiza határában. ${ }^{12}$

Az ásványi nyersanyagok iránti keresletnek a XVII. század közepén kezdődő hirtelen megnövekedése fellendítette Erdély bányászatát és kohászatát.

A fémkohászat felkarolására elsőként Köleséri Sámuel tesz javaslatot, 1717-ben megjelent Auraria Romano-Dacica címü müvében. 1762-ben a Báthori István alapította kolozsvári egyetemi rangú jezsuita akadémia (Lyceum) tanárai már egy professzori státus, illetve tanszék felállítását javasolják a kohászat elméleti alapjainak anyanyelven való tanítására. A kolozsvári (a jezsuita rend feloszlatása után piaristává lett) akadémia melletti kohászati iskola végül 1793-ban jöhet létre, Kémiai Metallurgiai Iskola néven, ásványtani, kémiai, élettani és gyógyszertani tanszékekkel. A négy tanszék első professzora a Zalatnáról Kolozsvárra kerülő André Étienne orvos és kémikus, akit 1797-ben bekövetkező halála után Moger Károly követ. Moger Károly vásárolta meg a főiskola számára Müller Ferenc Jó-

\footnotetext{
"Szabadváry Ferenc: i.m.

${ }^{11}$ Mátyus: $i . m$.

${ }^{12}$ Móra László - Próder István: A magyar kémia és vegyipar kronológiája 1800-1944. Sajtó alá rendezte Gazda István. Magyar Tudománytörténeti Intézet, Budapest, TKM Egyesület, Piliscsaba. 1997.
} 
zsef bányamérnök-mineralógusnak, a tellúr felfedezőjének gyüjteményét, amelybe harminc év munkájával Erdély legérdekesebb ásványait, kőzeteit és ősmaradványait gyủjtötte össze. Utóda 1809-től 1850-ig (a tanszék megszünéséig) Bergai József ${ }^{13}$ volt.

Az erdélyi kémiaoktatás és -kutatás következő nagy korszaka a Kolozsvári Tudományegyetemhez köthetö.

Erdély modern egyetemének létrehozását a kiegyezés tette lehetővé. A kolozsvári egyetem létesítésére vonatkozó döntés többéves huzavona után, 1872-ben születik meg, az egyetem alapítására vonatkozó javaslatot a magyar parlament 1872/XIX-es törvénycikkelye szentesíti. Négy kar felállításáról döntöttek: a Jog- és Államtudományi, Orvostudományi, Bölcsészet-, Nyelv- és Irodalomtudományi, valamint a Matematikai és Természettudományi Karéról. A négy karra 34 rendes és 5 rendkívüli egyetemi tanárt neveztek ki. Az egyetem ünnepélyes megnyitóját 1872. november 10-én, vasárnap tartották, másnap megkezdődött az oktatás mind a négy karon a beiratkozott 258 hallgatóval. ${ }^{14} \mathrm{Az}$ egyetem első választott rektora Berde Áron professzor, prorektora Brassai Sámuel. Segítségként az Erdélyi Múzeum-Egyesület nagy tudományos értéket képviselö könyvtárát és gyújteményeit bérbe adta az egyetemnek.

Berde Áron (1819-1892) ösztöndijasként, Németországban ismerkedett meg a vegyészet alapjaival. Az agrokémia első erdélyi müvelőjének és képviselőjének tekinthető. Mindennel foglalkozott, ami a természettudományok gyakorlati alkalmazását célozta. 1859-ben lefordította Stöckhardt A chemia iskolája címü mủvét, mely vegytani előadásainak alapjául szolgált. Ezt tekinthetjük az Erdélyben használt első kémiatankönyvnek. Az 1846-ban Takács Jánossal, a Református Kollégium tanárával együtt indított Természetbarát, Erdély első természettudományokkal foglalkozó lapja agrokémiai cikkeket is közölt. ${ }^{15}$

A kémiaoktatás és a vegyészeti kutatás szempontjából az egyetem Matematikai és Természettudományi Kara mellett meg kell említeni az Orvostudományi Kart is, bár igazán kimagasló szakmai eredmények természetszerüleg föleg a Természettudományi Kar kémia tanszékein születtek.

\footnotetext{
${ }^{13}$ Hints Miklós: i.m.

${ }^{14}$ Puskás Ferenc: A kolozsvári egyetem (1989-ig). Emlékkönyv a Firka 10 éves évfordulójára. Szerk.: Puskás Ferenc - Tibád Zoltán, Erdélyi Magyar Mủszaki Tudományos Társaság, Kolozsvár, 2001.

${ }^{15}$ Ajtay Ferenc: A kolozsvári házsongárdi temetőben pihenő természettudósok. Természet Világa, 131/11. (2000), 486-490.
} 
Röviden összefoglalva a vegytan tanszékek helyzetének alakulása az Egyetem alapításától kezdve:

Az Orvosi Kar 11 tanszékkel indult, ebböl egyik a Plósz Pál vezette Élet- és Kórvegytan. Az Élet- és Kórvegytani Tanszék további vezetői 1891től Udránszky László, majd 1911-től Veress Elemér. 1918-ban az Orvostudományi Kar kolozsvári keretében 17 tanszék szerepelt, a professzorok közül Issekutz Béla Szegedre ment át a Gyógyszertanra, Reinbold Béla az Orvosi Vegytanra. A második bécsi döntés után Kolozsvárra visszatért egyetem Orvostudományi Karán az Orvosi Vegytan Tanszékre a szegedi egyetemröl jött át Annau Ernő magántanár, a Gyógyszertanra pedig (a tihanyi Biológiai Intézetből) Méhes Gyula szegedi magántanár. ${ }^{16}$

A Matematikai és Természettudományi Kar az alapításkor öt tanszékkel indult, ezek egyike a Vegytan, egyike pedig a vele rokon Ásványtan. Bár a hallgatók számát tekintve a Matematika-, Természettudományi Kar volt a legkevésbé népes, a vegytanon néha ötvennél is több volt a jelentkező. Elsőéves korukban a gyógyszerészhallgatók is a kar diákjai voltak, itt vizsgáztak, csak másodévre kerültek át az orvosi karhoz.

A Vegytan Tanszék vezető professzora a pesti egyetem tanársegédi állásából idekerülő, doktori címmel rendelkező Fleischer Antal ${ }^{17}$ volt.

Fleischer Antal váratlan öngyilkossága után utóda 1878-tól a fővárosban magántanári címet szerzett igen fiatal és tehetséges Fabinyi Rudolf, a szerves kémia hazai úttörője, a kémia európai hírű művelője lett. Fabinyi vizsgálatai egyebek között új, szabadalmaztatott festékanyagok felfedezéséhez vezettek (a reakciót ma is Fabinyi-féle szalicil-aldehid reakció néven ismeri a szakirodalom). ${ }^{18}$ Jelentős eredményei voltak az analitikai kémia és a fizikai kémia területén is. Az elsők között foglalkozott a tüzelőanyag-cellás galvánelemek vizsgálatával, amelyeket ma sikerrel hasznosítanak az űrtechnikában. Kolozsváron 1881-83 között korszerü kémiai intézetet szervezett. ${ }^{19}$ A 30 helyiséges, emeletes, önálló épület 1884. október 31-i avatá-

\footnotetext{
${ }^{16}$ Gaal György: Egyetem a Farkas utcában. A kolozsvári Ferenc József Tudományegyetem elôzményei, korszakai és vonzatai. Erdélyi Magyar Müszaki Tudományos Társaság, Kolozsvár, 2001.

17 Gábos Zoltán: A Ferenc József Tudományegyetem természettudósai. Természet Világa, 129/3. (1998), 112-114.

${ }^{18}$ Móra László: Fabinyi Rudolf (1849-1920) szellemi hagyatéka. Firka, 1999-2000. (4), 136139.

${ }^{19}$ Hegyi Csilla: Fabinyi Rudolf (1849-1920). Firka, 1999-2000. (4), 145-148.
} 
sán részt vett Trefort Ágoston miniszter is. Az intézetben a kar hallgatóin kívül orvos- és gyógyszerésznövendékek is tanultak.

Ö alapította 1882-ben az első, magyar nyelven megjelenő kémiai tudományos folyóiratot, a Vegytani Lapokat, mely 1889-ben szünt meg. Számos elöadást tartott a kolozsvári társadalmi és szakmai egyesületekben, elsősorban az Erdélyi Múzeum-Egylet orvos- és természettudományi szakosztályának ismeretterjesztő estélyein. A Budapesten 1907-ben megalakuló Magyar Kémikusok Egyesületének Fabinyi Rudolf volt az első megválasztott elnöke.

Fabinyit tudományos érdemeiért a Magyar Tudományos Akadémia 1891-ben levelező, majd 1915-ben rendes tagjává választotta. Székfoglalójában Stereochemiai tanulmányok címen az azaril-aldoxim kísérleteinél észlelt sztereoizomériát ismertette, hazai kortársait évtizedekkel megelőzve.

Az SCI (Science Citation Index) 1945 és 1997 között megjelent éves köteteiben 81 Fabinyi-közleményre utalnak azok a külföldi szerzök, kik munkájuknál felhasználták eredményeit. Az azaronok kondenzációs termékeire vonatkozó munkáira a japán Kitahara a Heterocycles 1993-as évfolyamában utal.

1882-töl a kar felvehetett két ösztöndíjas vegyésznövendéket.

A Vegyészeti Tanszék mellett 1888-ban Vegykisérleti Állomás létesült.

A kar az első negyedszázadban tizenkét magántanárt képesített, közülük kettő vegyész volt: Ruzitska Béla és Koch Ferenc.

1913-ban Ruzitska Béla magántanár számára egy második vegytani (kémiai technológiai) tanszéket létesítenek. Ruzitska Béla főműve, a Bevezetés az elméleti kémiába 1894-ben jelent meg Kolozsváron. Élelmiszervizsgálati kémia címü kötete a budapesti Természettudományi Társulat kiadásában látott napvilágot.

A karnak a világháború elött tudományos szempontból rendkívüli teljesítménye volt, hiszen az akkori Magyarországon Kolozsváron kívül csak a főváros nyújtott lehetőséget (a mủegyetemen és tudományegyetemen) a természettudományok müvelésére és természettudósok képzésére. A kar kémiaprofesszorai közül egyébként csak az élelmiszerkémiában úttörő Ruzitska Béla nem lett tagja az akadémiának.

$\mathrm{Az}$ utolsó tanévben a két vegytan tanszéken a tanárok mellett egy adjunktus is működött, Széki Tibor, továbbá néhány tanársegéd és gyakornok. A vegytan tanszékek vezető tanárai nem hagyták el a kolozsvári egye- 


\section{EME}

temet: Fabinyi Rudolf 1920-ban meghalt, Ruzitska Béla pedig Kolozsvárt maradt. ${ }^{20}$

Az Egyetem 1940-es visszatérésekor újonnan jött tanárok közül meg kell említeni Szabó Zoltán budapesti magántanárt, szegedi kollégiumigazgatót (szervetlen és analitikai kémia), Budapestről Imre Lajost (általános és fizikai kémia) és Vargha Lászlót (szerves kémia). Az átvételnél a kolozsvári magyar értelmiség részéröl megjelent Ruzitska Béla is, a Ferenc József Tudományegyetem rendkívüli tanára.

Vargha László Szent-Györgyi Albert munkatársaként indult, s a magyar gyógyszerkutatás vezető egyénisége lett; Szabó Zoltán a reakciókinetika és a katalízis világviszonylatban számon tartott szaktekintélyévé vált.

A kolozsvári tudományegyetemnek ma négy örököse is múködik. Épületeit, felszerelését a kolozsvári I. Ferdinánd, majd a Victor Babeş nevét viselő egyetem kapta meg, szellemét a Bolyai János nevét felvevő magyar tudományegyetem vitte tovább. A kettő erőszakos egyesítése (1959) óta a Babeş-Bolyai Tudományegyetem az egyik örökös.

A másik a Bolyaiból kivált marosvásárhelyi Orvosi és Gyógyszerészeti Egyetem, különösen ennek magyar tanári kara.

A harmadik, negyedik pedig a szegedi, 1940-től Horthy Miklós, később József Attila nevét viselö Tudományegyetem, valamint az ebböl 1951-ben kivált, későbbi Szent-Györgyi Albert Orvostudományi Egyetem.

A négy utódintézményben (az időszakos nehézségek ellenére) mind a kémia oktatása, mind a kutatóvegyészet sikeres és eredményes. A BBTE Kémia és Vegyészmérnöki Karán dolgozó magyar oktatók 1990-2001 közötti kutatási eredményeit megtalálhatjuk Kékedy-Nagy László és Majdik Kornélia kellő alaposságú összefoglaló tanulmányában, a Tizenkét év. Összefoglaló tanulmányok az erdélyi magyar tudományos kutatások 1990-2001 közötti eredményeiröl (Sapientia Kiadó, 2002) ${ }^{21}$ második kötetében. Az 1945-1989 közötti számos eredmény még feldolgozásra vár.

\footnotetext{
${ }^{20}$ Ajtay Ferenc: i.m.

${ }^{21}$ Kékedy-Nagy László - Majdik Kornélia: Adatok az erdélyi magyar vegyészek tudományos kutatói tevékenységérôl. 1990-2001. = Tizenkét év. Összefoglaló tanulmányok az erdélyi magyar tudományos kutatások 1990-2001 közötti eredményeirōl. Szerk.: Tánczos Vilmos és Tökés Gyöngyvér. Sapientia Kiadó, Kolozsvár, 2002. II. 49-70.
} 